\title{
MEDICAL EDUCATOR'S NONVERBAL BEHAVIOR AND ITS IMPACT ON STUDENTS AND EDUCATIONAL ENVIRONMENT
}

\author{
Anbreen Aziza, Farzana Majeed ${ }^{b}$, Saadia Muneer Malik ${ }^{c}$
}

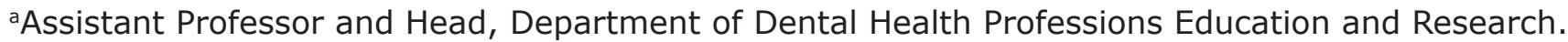
Army Medical College, National University of Medical Sciences (NUMS), Rawalpindi.

${ }^{b}$ Associate Professor, Department of Physiology, HBS Medical and Dental College, Shaheed Zulfiqar Ali Bhutto Medical University (SZABMU), Islamabad.

'Assistant Professor, Department of Oral Pathology, Army Medical College, National University of Medical Sciences (NUMS), Rawalpindi.

\section{ABSTRACT:}

BACKGROUND \& OBJECTIVE: Nonverbal communication has been overlooked in medical education. The purpose of this study was to explore student-teacher perceptions regarding impact of nonverbal behavior of medical educators on educational environment.

METHODOLOGY: A mixed method-study with convergent parallel design was conducted among purposively chosen final year students $(n=150)$ and medical teachers $(n=73)$ from three dental colleges of Islamabad. A web-based survey concerning three domains of kinesics (Facial expressions, Gestures, Head movement and postures) was developed and validated before execution. Comparison of participant's responses to closed-ended questions was done by applying Fisher's Exact Test and open-ended questions were thematically analyzed.

RESULTS: Response rate of students and teachers was $46 \%$ and $63 \%$ respectively. Five out of nine closed-ended questions gave statistically significant difference among student's and teacher's responses $(p \leq 0.05)$. Twenty-seven sub themes emerged from three domains of kinesics. Students revealed that happy mood of their teachers reduces boredom in the classroom and a teacher's smile lets them freely express anything, whereas anger produces fear among them. According to the educators a happy instructor inspires students to study and makes the environment friendly and an undemanding smile helps build a rapport with students. Moreover, positive gestures used by teachers encourage students to clarify concepts and upright posture brings energy and motivation to the classroom.

CONCLUSION: A teacher's nonverbal behavior has a profound effect on educational environment. A smile on a teacher's face creates a friendly and fearless environment whereas anger creates barriers to communication. A happy teacher can generate a pleasant and motivating learning environment. KEYWORDS: Behavior, Education, Medical, Undergraduate, Environment.

\section{How to cite this:}

doi: https://doi.org/10.37723/jumdc.v12i3.560

Aziz A, Majeed F, Malik SM. Medical Educator's nonverbal behavior and its impact on students and educational environment. Journal of University Medical \& Dental College. 2021;12(3):152-161.

doi: https://doi.org/10.37723/jumdc.v12i3.560

This is an Open Access article distributed under the terms of the Creative Commons Attribution License (http://creativecommons.org/licenses/by/4.0), which permits unrestricted use, distribution, and reproduction in any medium provided the original work is properly cited. 


\section{INTRODUCTION:}

Human are socially connected to each other with the help of communication ${ }^{[1,2]}$. In medical education communication remains a fundamental skill to be taught and learned; however more focus has been on developing competence in verbal communication in the last few decades ${ }^{[3]}$.As a matter of fact, communication not only includesspoken words (38\%), but also encompasses voice tone $(7 \%)$ and body language $(55 \%){ }^{[1,4]}$. Nonverbal communication (NVC)is everything minus the words we speak such as behavior of face, body and even voice ${ }^{[2,4]}$. Kinesicsis a type of NVC which includes facial expressions, body postures and body movements ${ }^{[5]}$. Other types are vocalics (volume and pitch of sound), oculesics (eye movement) and haptics (handshakes etc) [6].

Kinesics is the study of hand, arm, body and face movement and is the heart of nonverbal communication ${ }^{[5]}$. Previous studies regarding NVC have been done in various fields such as Islamic studies [7], psychology ${ }^{[8]}$, business [9], and patient-doctor interaction ${ }^{[10]}$ but use of NVC as a teaching strategy is yet to be explored in medical education ${ }^{[4]}$. Therefore, the purpose of this study is to qualitatively explore the impact of nonverbal behavior of medical educators on educational environment. The study will produce awareness among medical educators regarding use of nonverbal communication as a teaching strategy in medical education.

Corresponding Author:

Dr. Anbreen Aziz

Assistant Professor \& Head, Department of Dental Health Professions Education and Research. Army Medical College, National University of Medical Sciences (NUMS), Rawalpindi. Email: dranbreen@hotmail.com

\section{METHODOLOGY:}

A multi-center mixed method study with convergent parallel design using a web-based survey was carried out from July-September 2020 during COVID-19 lockdown phase. Ethical permission was taken from institutional Ethical Review Committee of three private dental colleges of Islamabad.

Purposive sample of final year students and medical educators (Assistant Professor and above) was included in the sampling frame. Students of all other years and junior teachers were excluded to get in-depth information from the senior most class and experienced teachers respectively. The survey was shared through the institutional WhatsApp group and emails of students and educators.

Majority of the participants were quite expressive and provided useful information regarding the topic of interest. AMEE 87 guideline regarding questionnaire development was utilized to develop open and closed-ended survey questions ${ }^{[11]}$. Out of a total of seven steps, four steps from the guide were followed that included: conducting a literature review, developing items, expert validation, and pilot testing. Extensive literature on the topic helped in making nineteen items for student's and fifteen for the teacher's questionnaire under three domains (face expressions, gestures, head movements and postures)of kinesics ${ }^{[1-4,6-9]}$. The survey was validated for content with five medical education experts. The items were then re-arranged, rephrased and omitted according to the expert's feedback. Pilot testing was conducted with students $(n=10)$ and teachers $(n=05)$ to manage any technical errors and to assess comprehension level. After corrections, the survey was finalized and approved by all authors. It consisted of fifteen items for students and nineteen for teachers. The survey was executed with informed consent to keep participation voluntary and anonymous. Quantitative and qualitative data were collected concurrently where as analysis was done independently to finally make an interpretation of results together.

Frequencies and percentages of demographics and closed-ended questions were calculated. Fisher's Exact Test was applied to see statistical difference among student's and teacher's responses. Open-ended questions were thematically analyzed using systematic approach for qualitative text analysis ${ }^{[12]}$. Thematic analysis was performed in the following steps:

1. Data preparation started with pasting all text replies of students and teachers against each open-ended question. Each reply was labelled with participant number to ensure anonymity. Each open-ended question was allotted a domain e.g., domain1, Impact of facial expressions. 
2. All authors did open coding after familiarizing with the data and then developed in-vivo analytic codes (1stcoding cycle) for each domain. Later, codes were arranged, and subcategories were formed. Data under each domain were again coded (2nd coding cycle).

3. Coding gave rise to sub theme formation. Later, a consensus among all authors regarding sub themes ensured analytical triangulation ${ }^{[13]}$.
4. Results are presented in the form of sub themes under each domain along with quotes taken from the text replies of the participants.

\section{RESULTS:}

The response rate of final year students and teachers was 69/ 150 (46\%) and 46/ 65 (71\%) respectively from three dental colleges (Table-I).

\section{Table-I: Characteristics of the study participants.}

\begin{tabular}{|c|c|c|}
\hline Characteristics & & N (\%) \\
\hline \multicolumn{3}{|c|}{ STUDENTS $(n=69)$} \\
\hline \multirow[b]{2}{*}{ Gender } & Male & $8(11.6 \%)$ \\
\hline & Female & $61(88.4 \%)$ \\
\hline \multirow{2}{*}{$\begin{array}{l}\text { Age Groups } \\
\text { (Years) }\end{array}$} & Y1: $20-22$ & $38(55 \%)$ \\
\hline & Y2: $23-25$ & $31(45 \%)$ \\
\hline \multicolumn{3}{|c|}{ TEACHERS $(n=46)$} \\
\hline \multirow[b]{2}{*}{ Gender } & Male & $11(23.9 \%)$ \\
\hline & Female & $35(76.1 \%)$ \\
\hline \multirow{5}{*}{$\begin{array}{l}\text { Age Groups } \\
\text { (Years) }\end{array}$} & A1: $25-35$ & $6(13 \%)$ \\
\hline & A2: $36-45$ & $31(67.4 \%)$ \\
\hline & A3: $46-55$ & $5(10.9 \%)$ \\
\hline & A4: $56-65$ & $3(6.5 \%)$ \\
\hline & A5: $66-75$ & $1(2.2 \%)$ \\
\hline \multirow[t]{3}{*}{ Teacher's Designation Groups } & T1: Professor & $10(21.7 \%)$ \\
\hline & T2: Associate Professor & $9(19.6 \%)$ \\
\hline & T3: Assistant Professor & $27(58.7 \%)$ \\
\hline \multirow{2}{*}{$\begin{array}{l}\text { Basic Sciences } \\
\text { Clinical Sciences }\end{array}$} & BS & $23(50 \%)$ \\
\hline & CS & $23(50 \%)$ \\
\hline \multirow{5}{*}{$\begin{array}{l}\text { Teaching Experience groups } \\
\text { (Years) }\end{array}$} & E1: $1-5$ & $19(41.3 \%)$ \\
\hline & E2: $6-10$ & $15(32.6 \%)$ \\
\hline & E3: $11-15$ & $8(17.4 \%)$ \\
\hline & E4: $16-20$ & $3(6.5 \%)$ \\
\hline & E5: $21-25$ & $1(2.2 \%)$ \\
\hline
\end{tabular}

* M: Male, F: Female, Y: Age Group of Students, A: Age Group of Teachers, T: Teacher's Designation Groups,BS: Basic Sciences, CS: Clinical Sciences, E: Teaching Experience Groups

\section{Results of closed-ended survey questions:}

Comparison of closed-ended questions asked from students and teachers are given in Table-II. Among nine closed-ended questions, five questions gave statistically significant difference among student's and teacher's responses $(p-\leq 0.05)$. 
Table-II: Comparison of closed-ended questions asked from students and teachers.

\begin{tabular}{|c|c|c|c|c|}
\hline \multicolumn{2}{|r|}{ DOMAINS/THEMES } & \multicolumn{2}{|c|}{ Frequency (\%) } & \multirow[t]{2}{*}{ p-value } \\
\hline & & Students $(n=69)$ & Teachers $(n=46)$ & \\
\hline & \multicolumn{4}{|c|}{ 1. FACIAL EXPRESSIONS } \\
\hline \multirow[t]{9}{*}{1} & \multicolumn{3}{|c|}{ Frequently used facial expression showing mood or emotions: } & \multirow{9}{*}{1.0} \\
\hline & Happiness/ Joy & $12(17.4 \%)$ & $35(76.1 \%)$ & \\
\hline & Sadness & $0(0 \%)$ & $2(4.3 \%)$ & \\
\hline & Anger/ Frowning & $3(4.3 \%)$ & $2(4.3 \%)$ & \\
\hline & Surprise & $1(1.4 \%)$ & $5(10.9 \%)$ & \\
\hline & Fear & $0(0 \%)$ & $1(2.2 \%)$ & \\
\hline & Disgust & $0(0 \%)$ & $0(0 \%)$ & \\
\hline & Anxiety & $1(1.4 \%)$ & $1(2.2 \%)$ & \\
\hline & Neutral expressions & $52(75.4 \%)$ & $21(45.7 \%)$ & \\
\hline \multirow[t]{8}{*}{2} & \multicolumn{3}{|c|}{ Frequently used facial expression shown as a personality trait: } & \multirow{8}{*}{1.0} \\
\hline & Excitement/ Energy/ Passion/ Enthusiasm & $22(31.9 \%)$ & $35(76.1 \%)$ & \\
\hline & Tiredness & $2(2.9 \%)$ & $0(0 \%)$ & \\
\hline & Confusion & $0(0 \%)$ & $0(0 \%)$ & \\
\hline & Frustration & $5(7.2 \%)$ & $0(0 \%)$ & \\
\hline & Shyness & $0(0 \%)$ & $0(0 \%)$ & \\
\hline & Boredom & $7(10.1 \%)$ & $0(0 \%)$ & \\
\hline & Neutral expressions & $33(47.8 \%)$ & $11(23.9 \%)$ & \\
\hline \multirow[t]{3}{*}{3} & \multicolumn{3}{|c|}{ Is teacher's smile a powerful communicative signal? } & \multirow{3}{*}{1.0} \\
\hline & Yes & $67(97.1 \%)$ & $44(95.7 \%)$ & \\
\hline & No & $2(2.9 \%)$ & $2(4.3 \%)$ & \\
\hline \multirow[t]{3}{*}{4} & \multicolumn{3}{|c|}{$\begin{array}{l}\text { Does teacher start lecture with opening or welcoming facial } \\
\text { expressions such as smile? }\end{array}$} & \multirow[t]{3}{*}{0.001} \\
\hline & Yes & $43(62.3 \%)$ & $43(93.5 \%)$ & \\
\hline & No & $26(37.7 \%)$ & $3(6.5 \%)$ & \\
\hline \multirow[t]{4}{*}{5} & \multicolumn{3}{|l|}{ Frequently used type of smile: } & \multirow{3}{*}{0.004} \\
\hline & $\begin{array}{l}\text { Social smile (voluntary smile or primarily } \\
\text { made for others) }\end{array}$ & $44(63.8 \%)$ & $16(34.8 \%)$ & \\
\hline & $\begin{array}{l}\text { Smiling with eyes (involuntary, } \\
\text { spontaneous, genuine) }\end{array}$ & $25(36.2 \%)$ & $30(65.2 \%)$ & \\
\hline & \multicolumn{4}{|c|}{ 2. GESTURES } \\
\hline \multirow[t]{4}{*}{1} & Frequently used gesture/ symbol: & & & \multirow{4}{*}{0.008} \\
\hline & OK sign with raised thumb & $11(15.9 \%)$ & $23(50 \%)$ & \\
\hline & $\begin{array}{l}\text { Circling index finger around the side of your } \\
\text { head (he/ she is crazy) }\end{array}$ & $1(1.4 \%)$ & $0(0 \%)$ & \\
\hline & $\begin{array}{l}\text { Rolling your hand over and over in front of } \\
\text { you (move on) }\end{array}$ & $6(8.7 \%)$ & $6(13 \%)$ & \\
\hline
\end{tabular}




\begin{tabular}{|c|c|c|c|c|}
\hline & $\begin{array}{l}\text { Pointing directly at learner (student) while } \\
\text { asking a question }\end{array}$ & $26(37.7 \%)$ & $9(19.6 \%)$ & \\
\hline & $\begin{array}{l}\text { Hand gesture to indicate size or shape of } \\
\text { an object }\end{array}$ & $35(50.7 \%)$ & $20(43.5 \%)$ & \\
\hline & $\begin{array}{l}\text { Hold the index finger with the thumb to } \\
\text { create a small circle (the "OK gesture") }\end{array}$ & $4(5.8 \%)$ & $4(8.7 \%)$ & \\
\hline & $\begin{array}{l}\text { Cutting motion with the hand horizontally } \\
\text { to the side says - "No. No way." }\end{array}$ & $6(8.7 \%)$ & $3(6.5 \%)$ & \\
\hline & Waving a finger to scold & $3(4.3 \%)$ & $2(4.3 \%)$ & \\
\hline & $\begin{array}{l}\text { Taking a palm (or both) closer to the chest } \\
\text { to show that we are truthful, caring, and } \\
\text { responsible (gesture to show gratitude and } \\
\text { appreciation towards the audience) }\end{array}$ & $9(13 \%)$ & $9(19.6 \%)$ & \\
\hline & A power grip (closing your hand into a fist) & $10(14.5 \%)$ & $1(2.2 \%)$ & \\
\hline 2 & Frequently used behavior or movements: & & & \\
\hline & Clicking pens & $3(4.3 \%)$ & $4(9.5 \%)$ & \\
\hline & Shaking legs & $4(5.8 \%)$ & $0(0 \%)$ & \\
\hline & Scratching & $4(5.8 \%)$ & $1(2.4 \%)$ & \\
\hline & Twirling hair & $3(4.3 \%)$ & $0(0 \%)$ & 0.001 \\
\hline & Fidgeting with fingers or hands & $15(21.7 \%)$ & $0(0 \%)$ & \\
\hline & Cough or throat clearing sounds & $19(27.5 \%)$ & $2(4.8 \%)$ & \\
\hline & $\begin{array}{l}\text { Rubbing one's hands together (something } \\
\text { dramatic or surprising coming) }\end{array}$ & $15(21.7 \%)$ & $3(7.1 \%)$ & \\
\hline & Glancing at watch or clock & $13(18.8 \%)$ & $5(11.9 \%)$ & \\
\hline & None of the above & $31(44.9 \%)$ & $27(64.3 \%)$ & \\
\hline & 3. HEAD MOVEMEN & AND POSTUI & & \\
\hline 1 & Frequently used head movements and postl & & & \\
\hline & $\begin{array}{l}\text { Head nod (head tilting up and down } \\
\text { to indicate agreement, acceptance, or } \\
\text { acknowledgement) }\end{array}$ & $54(78.3 \%)$ & $39(84.8 \%)$ & \\
\hline & $\begin{array}{l}\text { Putting hands on hips while standing } \\
\text { (power position) }\end{array}$ & $4(5.8 \%)$ & $0(0 \%)$ & 0.05 \\
\hline & Leaning back while sitting & $2(2.9 \%)$ & $4(8.7 \%)$ & \\
\hline & Leaning forward while sitting & $2(2.9 \%)$ & $7(15.2 \%)$ & \\
\hline & $\begin{array}{l}\text { Putting hand under the chin while sitting } \\
\text { with a group }\end{array}$ & $4(5.8 \%)$ & $4(8.7 \%)$ & \\
\hline & Putting hands in pockets & $3(4.3 \%)$ & $2(4.3 \%)$ & \\
\hline 2 & Frequently used types of postures: & & & \\
\hline & Standing & $60(87 \%)$ & $34(81 \%)$ & \\
\hline & Sitting & $5(7.2 \%)$ & $1(2.4 \%)$ & 0.11 \\
\hline & Both & $4(5.8 \%)$ & $7(16.7 \%)$ & \\
\hline
\end{tabular}


Results of thematic analysis of open-ended survey questions

This study has comprehensively explored the perception of students and teachers regarding the impact of facial expressions, gestures, head movements and postures of medical educators on educational environment. Twenty-seven subthemes emerged under three domains of kinesics after thematic analysis of the data. The representative quotes are mentioned under each subtheme (For abbreviations within brackets after each quote, see foot notes table-I).

Theme 1: Impact of facial expressions:

\section{1: Neutral facial expressions}

1.1.a: Focused teaching and learning According to students, neutral expressions of teachers help in grasping the concept in a better way as they can focus more on the lecture.

'Neutral expressions do help us to remain focused as we are not distracted by them' (F, Y1, S\#27)

Whereas teachers said that teaching becomes smooth and focused when their expressions are neutral. 'Neutral expressions of teachers help to keep focus on the subject' ( $M, A 2, T 2)$

'The teaching is smooth with neutral expressions' (M, A4, T2)

\section{1.b: Hesitation in asking questions}

Students said that teachers with neutral facial expressions do not appear friendly and they feel hesitation whenever they need to ask questions. 'When teachers are expressionless, we hesitate to ask questions from our teachers' ( $F, Y 1, S \# 43)$

\section{1.c: Maintaining Class decorum}

Teachers said that neutral expressions let us maintain decorum of our class.

'Class decorum is maintained if a teacher stays at a distance from students' ( $F, A 2, T 3)$

\section{1.d: Boring learning environment}

Students said that majority of their teachers use neutral expressions which makes the lecture boring. 'Neutral expressions are just boring' ( $F$, Y2, S\#17). 'We get bored due to monotonous tone and expressions' (F, Y1, S\#60)

\section{2: Happy mood of teacher}

1.2.a: Reduction in boredom or monotony Students said that happy mood of their teachers reduces boredom among students.

'Their lectures become something students look forward to...light-hearted conversations in between the lecture helps to reduce the monotony and boredom of a lecture' (F, Y1, S\#20)

\section{2.b: Friendly and motivating learning environment, developing urge for improvement}

Teachers were of the view that a teacher's mood has the ability to create a friendly and motivating learning environment and students develop an urge to improve their grades.

'The teacher's mood plays a particularly important role...If I am happy, the learning environment is relaxed' ( $F, A 2, T 2)$. 'Students develop an urge to improve their grades if their teachers seem happy' (M, A4, T1). 'Happiness always motivates students and makes the learning environment quite friendly' ( $F, A 3, T 3)$

\section{3: Smile on teacher's face}

1.3.a: Freedom of expression and barrierfree healthy learning

The students reported that a teacher's smile makes them more comfortable and encourages them to participate without fear of being wrong or being insulted while giving answers. The environment becomes comfortable, pleasant and communication becomes easy because a smile spreads happiness.

'A smiling teacher creates a good feeling among students and talking about me I feel no fear to discuss anything' (F, Y2, S\#10)

'One of my teachers has a constant smile on her face during lecture which gives huge relief... There is no fear of insult or harsh words from her if I do not answer her questions' (F, Y1, S\#38)

'Smile spreads smile and happiness in students and create friendly learning environment' ( $F, Y 1$, S\#69)

Teachers said that learning environment becomes healthy and productive by a smile on the teacher's face.

'A Smile is useful for tense and weak students' $(\mathrm{F}, \mathrm{A} 2, \mathrm{~T} 3)$

'Due to smile learning outcome is increased' ( $F$, A2, T3)

\section{3.b: Audience attraction}

A genuine smile has the power to attract an 
audience as told by one of the students.

'A genuine smile has power to attract audience... it somehow makes the topic easier to understand and even easier to remember' (F, Y2, S\#17)

\section{3.c: Motivation}

Students said they are motivated to further learn the topic in depth due to pleasant learning environment created by a teacher's smile.

'I am motivated to attend lecture when see my smiling teacher' ( $F, Y 1, S \# 6)$

\section{3.d: Helping rapport building}

A smile helps in rapport building according to the teacher's perspectives.

'A rapport can be built with students through a teacher's smile...A smile always welcomes others' ( $F, A 2, T 3)$

\section{3.e: Non-serious environment}

Apart from advantages of smile, teachers said that it may cause non-seriousness in the learning environment.

'Smile is wrongly perceived in our society... It distracts students too and the environment becomes non-serious' ( $M, A 4, T 2)$

\section{4: Anger on teacher's face}

\section{4.a: Fear in students}

According to students, anger instills fear of possible insult among students.

'Anger has tendency to make students fearful' (M, Y2, S\#2)

'There is fear of getting insulted by teacher' ( $F$, Y2, S\#9)

\section{4.b: Loss of interest in studies}

Students told that due to teacher's anger, it becomes hard to understand the topic. Anger also creates a negative effect on the learning environment and a student's participation and interest is lost.

'When I am unable to understand due to tense environment, I lose my focus and interest in studies' (F, Y2, S\#17)

'I am unable to participate in tense environment' $(F, Y 1, S \# 20)$

\section{4.c: Demotivation}

Anger discourages and demotivates students according to both student's and teacher's perspectives.

'Anger is discouraging and makes learning just a burden for us' (F, Y1, S\#39)

\section{4.d: Creation of communication gap due to stressful learning environment}

Students told that due to anger, it becomes difficult to communicate and the environment becomes tense and learning becomes a burden for students.

'Communication gap is created between student and teacher in stressful environment' ( $M, Y 2$, S\#27). Teachers were of the same point of view that anger inhibits interactive learning and creates a stressful learning environment.

'Anger effects negatively on students... creates stressful learning environment...creates communication barrier due to which learning is inhibited' (M, A4, T1)

\section{4.e: Undermining teacher's respect}

Teachers said that an angry teacher would not get student's respect.

'Students do not have respect for their angry teacher...they do not respond to them in class' $(F, A 3, T 1)$

\section{4.f: Control on students}

Apart from the disadvantages of anger told by participants, few teachers said that students can be controlled by angry expressions.

'Anger has the power to control students' (F, A2, T2)

\section{Theme 2: Impact of gestures:}

\section{1: Gestures}

\section{1.a: Better learning with special} connection

Use of hand gestures by teachers such as 'hand gesture to indicate size or shape of an object' helps in clarifying difficult concepts as told by students.

'Hand gestures clarify certain things and topic is better understood by us' (F, Y2, S\#08)

Teachers said that a special connection is built with use of gestures which also boosts student's confidence.

'Students feel special when teacher uses OK sign with raised thumb...increases our confidence' ( $F$, $\mathrm{A} 2, \mathrm{~T} 2$ ) 


\section{2: Behavior or movements}

\section{2.a: Confused and disruptive attitude}

One of the students reported that few movements just add confusion in the learning environment.

'Unnecessary movements affect learning environment by adding confusion and disruption' (M, Y1, S\#25)

According to teachers, movements like clicking pens etc. show confused attitude of teachers which distract students.

'Some movements show confused attitude of teachers and distract students' (F, A2, T3)

\section{2.b: Attention seeking}

Teachers said that certain movement like click of a pen can gain student's attention.

'Movement of pen and sounds of clicking make students attentive in the class' (F, A3, T1)

Theme3: Impact of head movements and postures:

\section{1: Head nod}

\section{1.a: Encouragement}

Head nod gives encouragement to students according to both students and teachers.

'I feel good when teacher agrees to my answer and I feel appreciated' (F, Y1, S\#28)

\section{2: Standing posture}

\section{2.a: Energy and motivation}

Students said that standing posture during lecture shows how passionate a teacher is and it brings energy and motivates them to learn.

'Standing teacher is good in a sense we remain motivated during class and our energy remains intact' (F, Y1, S\#45)

According to teachers, standing posture shows commitment of the teacher towards teaching.

'It gives a signal to students that the teacher is putting full effort in teaching' ( $M, A 4, T 1)$.

\section{2.b: Active learning environment}

Environment becomes active when teacher is standing and teaching. This was told by teachers in our study.

'Standing posture makes direct eye contact with all students....it transfers energy among students' $(F, A 3, T 1)$

\section{DISCUSSION:}

This study has explored perceptions of key stakeholders i.e.,students and teachers regarding impact of nonverbal behavior (facial expressions, gestures, head movements and postures)of medical educators on educational environment. Findings of a previous study [14] depict that nonverbal behavior does impact undergraduate medical education. Common findings among both studies are motivating classroom environment due to happy mood of teachers and smile on their faces.

Additional aspects highlighted in our study are fear in students, loss of interest in studies, loss of motivation, stressful learning environment and undermining teachers respect due to anger on a teacher's face. Literature provides evidence that anger is the causative factor for under mining teacher's respect by students ${ }^{[15]}$ and it also effects teachers to ${ }^{[16]}$. However, a smile on teacher's face attracts audience, provides healthy learning environment without any barriers, and inculcates motivation among students. Moreover, it also helps in rapport building among students. Various rapport building behaviors in literature are the courteous nature, connecting and information sharing nature of teachers ${ }^{[17]}$. A single opinion of teacher worth mentioning here about anger is that it can control students within class. A worth mentioning teacher's opinion about a smiling educator is that it could create a nonserious environment if wrongly perceived. Well, it has already been beautifully explained in the literature that teacher's smile within a class could invite student's smile ${ }^{[18]}$. One of the students in this study said that "a smiling teacher creates a good feeling among students".

Participants while commenting on neutral expressions told that they help in smooth and focused teaching, but they create boring environment and students often hesitate to interrupt the monotony and ask questions.

On the other hand, a pleasant teacher's attitude reduces student's boredom and motivates them to study and improve their grades. It is therefore a teacher's responsibility to provide good environment to their students apart from various teaching skills to promote classroom learning [19]. Regarding gestures, the participants said that they provide better learning experience as in previous studies ${ }^{[20,21]}$ such as hand gestures help in clarification of concepts when teachers use them along with speech. It is reported 
that students feel special when a teacher uses gestures during teaching sessions. Teacherstudent relationship is of prime importance as it can greatly impact a student's academic and social development ${ }^{[22]}$. Therefore, gestures play an important role in imparting spark to the teacher's speech ${ }^{[23,24]}$. Whereas few unnecessary movements and behaviors were labeled disruptive by the students such as clicking pen by teacher, looking at the clock, throat clearing or leg shaking. On the other hand, teacher's point of view was different as one of the teachers told that clicking pen can be used to gain student's attention. Nonverbal message has the potential to transfer a person's attitudes and feelings to others therefore it is more effective than verbal messages $^{[1]}$.

Standing posture of teacher during lectures creates an active learning environment. A teacher's position and movement in the classroom plays a great role in transmitting a message to the students hence, a teacher should use correct posture to provide better learning experience to the students ${ }^{[25]}$. This study is unique in highlighting the positive and negative impact of nonverbal behavior of medical educators on educational environment by collecting data from the relevant stakeholders. But due to COVID-19 SOPs, face-to-face interviews or focus groups were not conducted. Moreover, all the seven steps for questionnaire development were not followed.

\section{CONCLUSION:}

Strategies in nonverbal communication should be given due importance by medical educators to have a positive impact on students and the learning environment. They should make a consistent effort to deliver their knowledge and skills in a pleasant demeanor and avoid letting their personal frustrations spill over in the classroom as they can negatively impact learning and confidence building.

A suggestion is being floated among the curriculum developers to integrate nonverbal communication strategies within the curriculum. This will be part of faculty development programs at the institutional level. Future research could be done to make and validate Likert scale questionnaire by following all the seven steps from AMEE guide 87 and the data could be collected from other health professions such as medicine, nursing, pharmacy, and physiotherapy to get broader perspectives. Moreover, other aspects of nonverbal communication like oculesics, vocalics and haptics could be assessed.

\section{ACKNOWLEDGMENT:}

We thank all institutes for permission and facilitation along with students and teachers who participated in the study.

CONFLICT OF INTEREST: None.

GRANT SUPPORT \& FINANCIAL

DISCLOSURE: None.

\section{REFERENCES:}

1. Bambaeeroo F, Shokrpour N. The impact of the teachers' non-verbal communication on success in teaching. Journal of Advances in Medical Education \& Professionalism. 2017;5(2):51-59.

2. Patterson ML. Nonverbal communication. Reference Module in Neuroscience and Biobehavioral Psychology. Missouri: Elsevier.2017.Doi: 10.1016/B978-0-12809324-5.06502-0

3. Piza F, Piza $P$, Schwartzstein RM. The power of nonverbal communication in medical education. Medical Teacher.2018;41(4):476-477. Doi: 10.1080/0142159X.2018.1454590

4. Hale AJ, Freed J, Ricotta D, Farris G, Smith CC. Twelve tips for effective body language for medical educators. Medical Teacher. $2017 ; 39$ (9):914-919.Doi : 10.1080/0142159X.2017.1324140

5. Liu C, Calvo RA, Lim R. Improving medical students' awareness of their non-verbal communication through automated nonverbal behavior feedback. Frontiers in ICT. 2016;3:1-13. Doi: 10.3389/fict.2016.00011

6. Gabbott M, Hogg G. The Role of Non-verbal Communication in Service Encounters: A Conceptual Framework. Journal of Marketing Management. 2001;17(1-2):5-26. Doi: $10.1362 / 0267257012571401$

7. Ali SS, Ishtiaq $M$, Khan $M$. Conversation Analysis of Muhammad (PBUH) for exploring his Effective Use of Nonverbal Communication including Paralinguistic Features. Rahat-ulQuloob. 2019;3(2):75-86.Doi: 10.51411/ rahat.3.2(2).2019.229

JUMDC Vol. 12, Issue 3, July-September, 2021 
8. Hall JA, Horgan TG, Murphy NA. Nonverbal communication. Annual Review of Psychology. 2019;70:271-294. Doi: 10.1146/annurevpsych-010418-103145

9. Wisankosol P. The Significance of Nonverbal Communication in Business. Academic Journal of Bangkok Thonburi Univeristy. 2018;7(2):234-242.

10. Kee JW, Khoo HS, Lim I, Koh MY. Communication skills in patient-doctor interactions: learning from patient complaints. Health Professions Education. 2018;4(2):97106. Doi: 10.1016/j.hpe.2017.03.006

11. Artino AR, Rochelle JSL, Dezee KJ, Gehlbach $\mathrm{H}$. Developing questionnaires for educational research : AMEE Guide No . 87. Medical Teacher. 2014;36(6):463-474. Doi: 10.3109/0142159X.2014.889814

12. Kaiser G, Presmeg N. compendium for early career researchers in mathematics education: qualitative text analysis: A Systematic Approach. Hamburg: Springer. 2019.Doi: 10.1007/978-3-030-15636-78

13. Guba EG, Lincoln YS. Epistemological and methodological basis of naturalistic inquiry. Educational communication and technology; A Journal of theory, Research and Development. 1982;30(4):233-252.

14. Butt MN, Iqbal M. Teacher's perceptions regarding facial expressions as an effective teaching tool. Contemporary Issues in Education Research. 2011;4(2):11-14.

15. Rahmtalla EMA. Investigating the impact of teachers' personal and professional characteristics on beginners' learning of english language. A case study of 5 th class Basic schools [Dissertation]. Khartum, Sudan: Nile Valley University.2016.

16. Burić I, Frenzel AC. Teacher anger: New empirical insights using a multimethod approach. Teaching and Teacher Education. 2019;86:1-11. Doi: 10.1016/j. tate.2019.102895

17. Webb N, Barrett LO. Student views of instructor-student rapport in the college classroom. Journal of the Scholarship of Teaching and Learning. 2014;14(2):15-28. Doi: $10.14434 /$ josotl.v14i2.4259

18. Jakonen T, Evnitskaya N. Teacher smiles as an interactional and pedagogical resource in the classroom. Journal of Pragmatics.
2020;163:18-31. Doi: $\quad 10.1016 / j$. pragma.2020.04.005

19. Dalaf M. Refrain and hesitation of EFL students in class oral participation: problems and solutions. Al -Adab Journal. 2019;128(128):137-152.

20. Barmaki R, Hughes CE. A case study to track teacher gestures and performance in a virtual learning environment. Proceedings of the Fifth International Conference on learning analytics and knowledge. 2015:420-421. Doi: $10.1145 / 2723576.2723650$

21. Yeo A, Ledesma L, Nathan MJ, Alibali MW, Church RB. Teachers' gestures and students' learning: sometimes "hands off" is better. Cognitive Research: Principles and Implications. 2017;2(41):1-11. Doi: 10.1186/s41235-017-0077-0

22. Baruch AF, Hershkovitz A, Ang RP. Teacherstudent Relationship and SNS-mediated communication: perceptions of both roleplayers. Interdisciplinary Journal of e-Skills and Lifelong Learning. 2015;11:273-289. Doi: $10.28945 / 2329$

23. McNeill D. Why we gesture; The surprising role of hand movements in communication. cambridge: Cambridge University Press; 2015. Doi: $10.1017 /$ cbo9781316480526.010

24. Roth WM. Gestures: Their role in teaching and learning. Review of Educational Research. 2001;71(3):365-392. Doi: $10.3102 / 00346543071003365$

25. Restuningrum NR. Teachers' strategy of positioning in teaching young learners. International Journal of Educational Best Practices. 2018;2(1):1-13. Doi: 10.31258/ ijebp.v2n1.p1-13

\section{AUTHOR'S CONTRIBUTION:}

Anbreen Aziz: Study design, questionnaire development, thematic analysis, manuscript finalization after proofreading.

Farzana Majeed: Pilot testing, data collection, Analysis (Table-II).

Saadia Muneer Malik: Thematic analysis, manuscript drafting.

Submitted for Publication: 15-02-2021 Accepted After revision: 29-06-2021 